Barbara Majewska ${ }^{1}$

Czestochowa University of Technology, Faculty of Management

Institute of Logistics and International Management

\title{
An international network sporting event based on the example of the Four Hills Tournament
}

\begin{abstract}
The major research objective of the paper is to identify the essence of international sporting events, whose network nature is related to organizational links between cities, sports associations, the media, sponsors and other stakeholders. The analysis is based on the example of a cyclical event - the Four Hills Tournament. The stakeholder analysis was carried out and a model of network management of the relationship and organization of the sporting event was indicated. The history of the Tournament was also discussed in conjunction with the marketing, organizational and technological trends that have changed over the years.
\end{abstract}

Keywords: network of connections, ski Jumping, Four Hills Tournament, sporting event

\section{Introduction}

The organization of sporting events includes a number of services such as, for instance, planning, finding sponsors, team management, social media activities, negotiations, services for event participants or a comprehensive technical and logistical implementation. Therefore, it is a combination of diverse, but complementary activities. In addition, due to the increasing difficulties occurring during the organization of major sporting events, international network events are becoming increasingly important. Due to this approach in managing a sporting event, the scope of activities is much broader, thus distributing costs while increasing profit for individual stakeholders. What networking here means is focusing attention on the relationship between the main entity and its environment. The essence of the relationship between stakeholders of the event determines organizational activities carried out professionally. A well-prepared sporting event looks great in the media, which, in turn, allows the promotion of brands, cities and entire regions.

The research objective of the study is to identify the essence of international sporting events whose network nature concerns organizational links between cities, sports associations, media, sponsors, and other stakeholders. The article is both

${ }^{1}$ Barbara Majewska, e-mail: basia_majewska@poczta.fm, ORCID: 0000-0002-0489-3729 
theoretical and empirical. The first part presents a review theoretical analysis related to the organization of sporting events, highlighting the importance of networking and stakeholder relationships. The second part contains the results of empirical research. In order to illustrate the research thesis, an example of an international sporting event was used, which is the Four Hills Tournament. Its network nature has been visible for several decades. The descriptive analysis method was applied in the study. Also, the observation method was used to classify event sponsors.

\section{Organization of sporting events in the network dimension}

Sporting events, apart from extraordinary emotional experiences, bring about significant economic effects generating profits for clubs, sports arenas, cities, local entrepreneurs and sponsors. The organization of world-scale events can also affect the increase in tourist traffic in the region, improve economic conditions or the implication of socio-ecological initiatives (Shipway, Fyall 2012). The organization of sporting events requires comprehensive actions based on stable relations between stakeholders. Indicating strong and stable relations between stakeholders of sporting events translates into desirable market behaviour of all entities. This leads, in turn, to the strengthening or improvement of the position of the event on the international stage, emphasizing its significance as well as importance for fans or players. The consequence of such a strong position of the event in the minds of all stakeholders is setting a higher price for tickets, contracts with the media and sponsors. Such activities contribute to building shareholder value, which in the case of network sporting events applies to host cities or sponsors. The possibilities of establishing such relationships depend on the organization's ability to build trust, mutual understanding of the parties to the relationship, a long-term perspective of cooperation, communication and mutual involvement in the continuous development of relationships (Rudawska 2011).

The literature on sporting events lacks references to the network dimension. However, the importance of building relationships between stakeholders is increasingly emphasized. Relationship marketing is related to sports marketing, which indicates the importance of relationships, not only within the organization or the immediate environment, but with all stakeholders. However, more attention should be paid to the changing socio-economic conditions. The importance of networking as an opportunity to maintain the importance of international sporting events should also be emphasized.

When discussing the essence of the network of sporting events, one should take into account the numerous benefits that the host cities of a given international sporting event gain. First of all, organizing of sporting events translates into job creation, the arrival of an increased number of tourists from abroad, or the launch of new investments and global promotion of the entire country, as well as the huge profits of cities, various stakeholders or complementary services. The benefits of creating international sports games are primarily the ease of communication with the customer, because sporting events appeal to a larger audience in the world, so it is easier to promote and sell them anywhere. Secondly, sporting events have a greater 
impact on society due to the fact of emotional experiences or a sense of belonging to a group of supporters and building relationships with teams or sportsmen representing cities or the country. In the long run, sporting events can also use the city's image, because they attract huge interest of many recipients, including cities and brands that invest money in and make efforts to support a given event (Herstein, Berger 2013). Therefore, city authorities are competing with each other for obtaining the status of the organizer of prestigious sporting events, which proves that these events have a beneficial effect on the city, despite the costs of organization and expensive accompanying investments. Although most events are of a short-term nature, they still contribute to promoting the city internationally, making it perceived as more attractive, both for investors and tourists, which in the long run can bring benefits in the form of a constant inflow of capital, people and constant initiating infrastructure development (Budner 2012). The implementation of major sporting events potentially provides opportunities to generate countries' attractiveness, even if they have unattractive political characteristics. However, countries attempt to attract others through actions that create a positive impression and increase understanding among foreign recipients (Grix, Lee 2013).

Currently, sports organizations are compared to medium-sized enterprises in terms of the number of employees and the annual turnover (Nufer and Bühler 2010). The situation is similar in the case of organizers of sporting events, because they concentrate representatives of many different industries. Therefore, the quality and professionalism of people managing these entities grow in importance. Increasingly, the main decision-makers in sports organizations are management specialists that are aware of the need to use various management techniques to improve the efficiency of the event and strengthen its image in the environment. Changing conditions on the international stage are causing a growing demand for a marketing approach to sport management. This means that all decisions and actions should lead to satisfactory meeting of the needs of individual stakeholders (Rudawska 2011).

The organization of sporting events is also related to sponsorship. The cost of professional creation of events, especially those on an international scale, is enormous, which compels the use of sports marketing tools. For potential sponsors this is a great opportunity to build their brand and strengthen its publicity. In the literature, sports sponsorship is defined as an activity involving financial support, through the services or physical means of sportspersons, sports organizations or events, in exchange for the services of sponsored entities that achieve the sponsor's promotional and communication goals (Ivan 2010). The sponsor's efforts, which contribute to the success of a sporting event, translate into a positive assessment of the investor in two ways. On the one hand, being an official sponsor can be considered as brand promotion through a credible reference to the recipients of advertising messages, i.e., consumers, investors and shareholders. In this sense, it is expected that sports sponsorship, understood as a unique advertisement, will convince the current investor and shareholder to make additional investments or to attract new investors to buy the shares of the sponsoring company and customers to buy the offered products. On the other hand, a sponsoring company can enjoy a long-term positive and socially responsible image of a sports sponsor. By sponsoring a sporting event, the company can offer many players the opportunity to work in a stable financial 
environment. Taking this into account, a sponsoring company can be considered as a good scholarship funder who fully understands social responsibility, which leads to increased investment on the part of investors. Therefore, sports sponsorship is expected to improve the financial value of the sponsoring company (Kim 2010).

From the point of view of internationality or cross-border events, it is worth paying attention to networking between stakeholders. The cooperation of the organizers with other participants, as well as between them, affects the building of a network of relationships. Networking means focusing attention on the relationships between the main element and the entities of its environment (Czakon 2005). Krzyżanowski distinguishes two types of relation, i.e., relations, ruled as those occurring between two or more objects in the epistemological sense and interactions that actually occur between two or more real objects. The first of these relationships distinguishes relationships due to their spatial location, temporal succession, size, functions, similarity, belonging, congruence, compliance. The second type is a concrete phenomenon, defined in terms of time, place and material, energy or information flow. The real existence of flows in the network of sports organizations or during events is beyond doubt. Thus, the definition of a network essentially refers to interactions referred to as ties (Krzyżanowski 1999).

\section{The history of the Four Hills Tournament}

The Four Hills Tournament organized in Germany and Austria is an international network sporting event. The idea of playing the New Year ski jumping competition originated in 1921, but the first tournament was not played until 1953. After the reincorporation of the German Ski Association (DSV) into FIS in 1949, a joint New Year competition was immediately organized. In May 1952, at Night Ski Jump at Seegrube, the organization chart of the 'German-Austrian jumping tournament' was created, covering three locations: Partenkirchen, Innsbruck and Bischofshofen. However, it was necessary to find a second German partner because of the parity of the German and Austrian Ski Association. Ultimately, the bet was Oberstdorf.

The first tournament began with a New Year's jump in GarmischPartenkirchen in 1953 in front of 20,000 fans. The competitors came from six countries (except the best German and Austrian sportspersons - four Swedes, three Norwegians and three Swiss and five ski jumpers from Slovenia). Then the competition was held in the other three cities, creating a new network of connections between clubs and hosts.

In the following years, it was necessary to overcome a number of political and natural obstacles. There were problems related to visa requirements for entry to Germany and Austria or travel from one country to another. In addition, other ambiguities arose, such as, for instance, the GDR flag dispute and similar political difficulties that had to be overcome in order to make the tournament a cyclical event. Political problems could be resolved through cooperation. In spite of the obstacles, the rank of the tournament was increasing from year to year to achieve even greater success. 


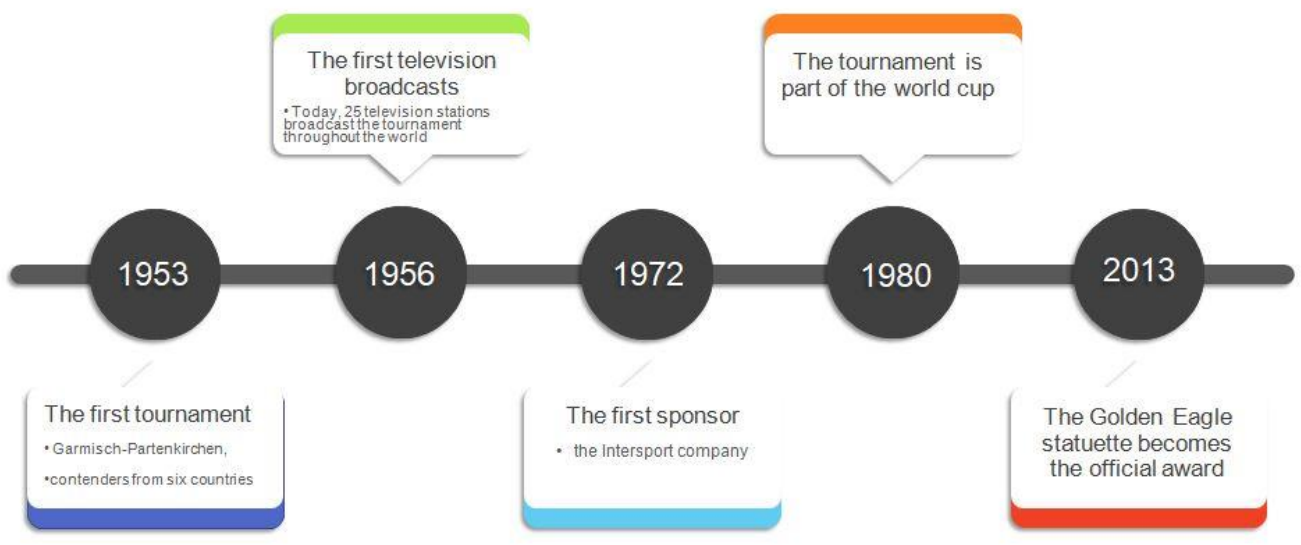

Figure 1. The Four Hills Tournament history timeline

Source: Own study based on www.vierschanzentournee.com/en/fans/geschichte (reading February 22, 2019).

Over the next decades, the organizers adapted to technological progress and changing management trends. Already in 1956 Bayerische Rundfunk broadcast the New Year ski-jumps on television and significantly contributed to the popularity of the tournament, and since 1960 the tournament has also been broadcast by other television stations. At present, 25 stations broadcast the tournament worldwide. Since 1962, the results have been analysed by computers, which allowed for more efficient running of the competition and increasing the popularity of the discipline on the international stage. Along with the development of sports marketing, in 1972 cooperation with the sponsor, i.e., the Intersport company, began and for over 25 years a stable relationship with the organizers was being created and this significantly contributed to the success of the tournament. The group of major sponsors of the event included such companies as Milka, Audi, Generali, Honda or Jack Wolfskin. An important point in the history of the tournament was connecting it with the World Cup, and creating a unique cup for the winner in the form of the Golden Eagle statuette, which has been a characteristic element of the tournament to this day. If a network event is to apply to all event organizers, it is important to set specific organizational principles. Nowadays, in accordance with the binding regulations, the heads of four ski clubs from the tournament's host cities change successively the function of the president of the entire event every three years (https://www.vierschanzentournee.com/en/fans/geschichte).

\section{The network nature of the Four Hills Tournament}

Over the years the organizers of the Four Hills Tournament have developed a specific image of this competition. Its rank is indisputable, despite the fact that new, guaranteeing high prizes, tournaments are being created, such as, for example, the 
Norwegian Raw Air. The network and cross-border nature of the tournament depends on conducting competitions in four different cities in two countries. The German Oberstdorf and Garmich-Partenkirchen commence the tournament, and immediately after the New Year's competition, the time comes for the Austrian part in Innsbruck and Bischofshofen, ending the competition on January 6.

Strong relationships built with contenders, supporters or companies supporting the tournament point to unwavering interest in competitions. In addition, the tournament displays certain distinctive features when compared with other international events (Figure 2). First of all, the main organizers of the tournament are four sports clubs representing individual cities. Local governments, tourist organizations and entrepreneurs from host cities are also becoming increasingly involved in the organization. It is important to organize additional attractions, as well as substitution services, which from the point of view of the tourist-fan will support the implementation of activities related to the tournament. Another element characteristic of this tournament is the financial prize of 20,000 Swiss francs, or the prize for winning the qualifying competition at the level of 5,000 euros. Especially the last award serves as an example of the event's network nature, since the sponsor of the award in each city is a different company, adjusted in such a way as to best influence the target group of its clients. New technical solutions are also tested during the tournament to attract even more attention from supporters and other stakeholders.

- Skiclub 1906 Oberstdorf

- Skiclub Partenkirchen

- Sport Club Bergisel

- Skiclub Bischofshofen

ORGANIZER

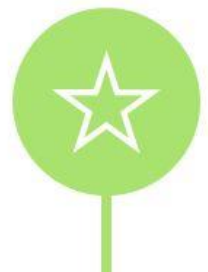

- The main prize of 20,000 Swiss francs

- The prize for the first place in the qualifiers is 5,000 euros

\section{PRIZES}

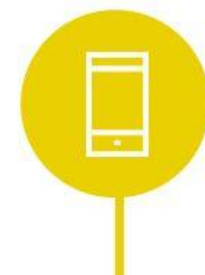

- Over 100 thousand spectators gathered under the hills

- Over 74 million viewers in front of TV sets

FANS



Figure 2. Characteristics of the Four Hills Tournament

Source: Own study based on the research conducted.

Every year, a set of fans gather in the vicinity of the German and Austrian hills, and those who failed to purchase tickets participate in the event in special fan zones in the host cities, or via TV broadcasts. There are over 100,000 places prepared for spectators under the four hills (Figure 3). Most fans, almost 27,000, can support their favourites in the first competition in Oberstdorf. The New Year's competition in Garmich-Partenkirchen, which is already a tradition, attracts the largest audience in 
front of TV sets. The ski jump in Austrian Innsbruck offers the lowest number of places. The last stop of this tournament is Bischofshofen, where 26 thousand tickets prepared are waiting for fans.



Figure 3. Number of places made available to fans as per individual hills

Source: Own study based on https://www.vierschanzentournee.com/en.

Currently, the Four Hills Tournament is a worldwide event, widely commented in the media and among the public. Therefore, it became necessary to create a characteristic logo compatible with the vision of the tournament. The logo contains four stripes of different colour corresponding to individual host cities. Each city is assigned a specific colour and its own unique but unambiguous logo. Such activities are aimed at building relations between cities, highlighting the shared purpose and coordination of activities. Figure 4 shows the main logo of the tournament as well as those assigned to individual cities.
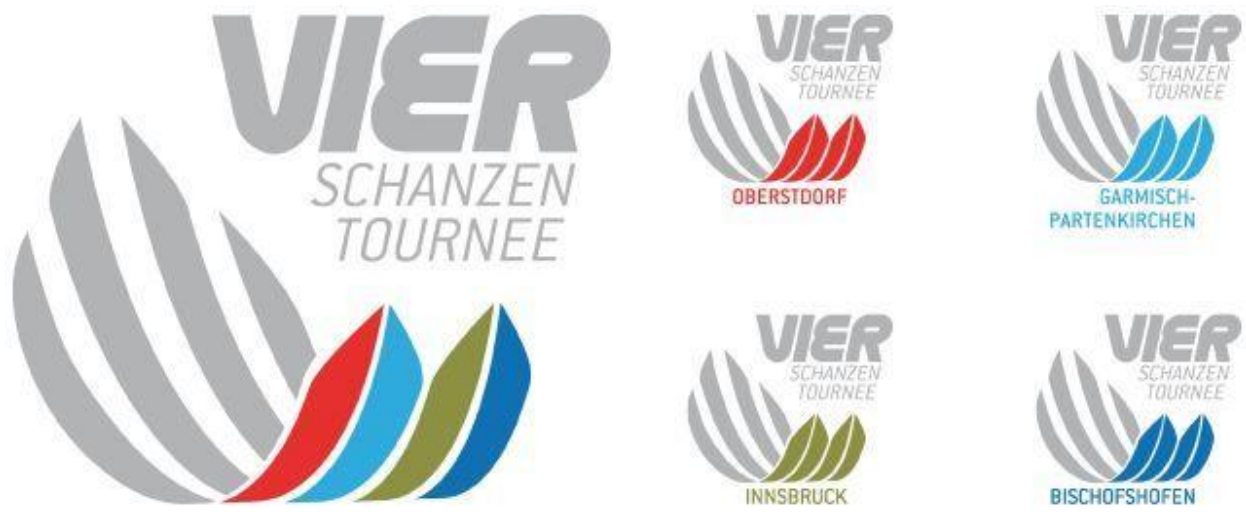

Figure 4. The logo of the Four Hills Tournament and of individual competitions Source: https://www.vierschanzentournee.com/en.

Marketing activities while organizing this sporting event are based on attracting sponsors and developing stable relationships with them. Enterprises that have decided to cooperate with the organizers have been connected with winter sports 
for years, despite the fact that their activities have no connection with sport. Only the official sponsor, i.e., the Polish sportswear brand $4 \mathrm{f}$, is a reflection of the relationship based on the close links of physical activity. The $4 \mathrm{f}$ company has replaced the Audi group, and thus has become the main sponsor of the entire tournament. The company logo will be incorporated into the official logo of the Four Hills Tournament over the next four years. The company logo was also placed in the most important points of the competition. An additional advantage and opportunity for the company's development is the special clothing line referring to the tournament, sold both by the official online store and under the hills on the days of the tournament. The other sponsors of the Four Hills Tournament are German companies, which indicates the willingness of the organizers to support local entrepreneurs. Two global brands, which are the main sponsors of ski jumping, such as Audi or Viessmann, are imposed. For many years, the sponsors of events related to ski jumping remain the same companies, which indicates the stability of partner relations. Relationships and networking between sponsors are characterized by a clearly visible breakdown shown in Table 1.

Table 1. Sponsors of the Four Hills Tournament

\begin{tabular}{|c|c|c|c|}
\hline Company & Characteristics & Logo location & Country \\
\hline \multicolumn{4}{|l|}{ Official sponsor } \\
\hline & $\begin{array}{l}\text { Sportswear } \\
\text { brand }\end{array}$ & $\begin{array}{l}\text { plastrons (Bischofshofen) } \\
\text { score board, LED boards, } \\
\text { coach tower, jumping } \\
\text { platform, a step and repeat } \\
\text { banner (used during } \\
\text { starts), a step and repeat } \\
\text { banner (used while } \\
\text { awarding winners), exit } \\
\text { gate, spots and } \\
\text { advertising materials, } \\
\text { inflatable portable arches }\end{array}$ & Poland \\
\hline \multicolumn{4}{|c|}{ Tournament sponsors } \\
\hline & $\begin{array}{l}\text { The Hörmann } \\
\text { Group is } \\
\text { Europe's largest } \\
\text { supplier of } \\
\text { doors and gates. }\end{array}$ & $\begin{array}{l}\text { ski plastrons (Innsbruck), } \\
\text { protective barriers around } \\
\text { the hill, a step and repeat, } \\
\text { banner (used while } \\
\text { awarding winners), spots } \\
\text { and advertising materials, } \\
\text { inflatable portable arches }\end{array}$ & Germany \\
\hline 8 & Building centre & $\begin{array}{l}\text { ski plastrons, protective } \\
\text { barriers around the hill, a } \\
\text { step and repeat banner, } \\
\text { (used while awarding } \\
\text { winners), spots and } \\
\text { advertising materials }\end{array}$ & Switzerland \\
\hline & $\begin{array}{l}\text { Manufacturer } \\
\text { of engine oils }\end{array}$ & $\begin{array}{l}\text { protective barriers around } \\
\text { the hill, a step and repeat } \\
\text { banner (used during } \\
\text { starts), a step and repeat }\end{array}$ & Germany \\
\hline
\end{tabular}




\begin{tabular}{|c|c|c|c|}
\hline & & $\begin{array}{l}\text { banner, (used while } \\
\text { awarding winners), spots } \\
\text { and advertising materials }\end{array}$ & \\
\hline (8) & $\begin{array}{l}\text { A leading } \\
\text { producer on the } \\
\text { low-alcohol } \\
\text { beverages } \\
\text { market }\end{array}$ & $\begin{array}{l}\text { ski plastrons (the German } \\
\text { part), protective barriers } \\
\text { around the hill, a step and } \\
\text { repeat banner (used } \\
\text { during starts), spots and } \\
\text { advertising materials }\end{array}$ & Germany \\
\hline \multicolumn{4}{|l|}{ FIS sponsors } \\
\hline & $\begin{array}{l}\text { Manufacturer } \\
\text { of passenger } \\
\text { cars }\end{array}$ & $\begin{array}{l}\text { protective barriers around } \\
\text { the hill, a step and repeat } \\
\text { banner (used during } \\
\text { starts), a step and repeat } \\
\text { banner (used while } \\
\text { awarding winners), spots } \\
\text { and advertising materials }\end{array}$ & Germany \\
\hline VIESMANN & $\begin{array}{l}\text { A company } \\
\text { specializing in } \\
\text { heating systems }\end{array}$ & $\begin{array}{l}\text { protective barriers around } \\
\text { the hill, a step and repeat } \\
\text { banner (used during } \\
\text { starts), a step and repeat } \\
\text { banner (used while } \\
\text { awarding winners), spots } \\
\text { and advertising materials }\end{array}$ & Germany \\
\hline
\end{tabular}

Source: Own study based on the research conducted.

The need for cooperation, certain compromises or restrictions depend on the marketing standards adopted by the ski association and sports clubs. It should also be noted that during the competition there are also visible brands that represent individual sponsors of individual players or entire national teams and associations, which challenges the organizers to effectively display their sponsors.

Creating international sporting events poses not only marketing challenges, but above all organizational and technological ones. All three aspects of management are necessary and must be implemented in conjunction with each other so that the final result is satisfactory for all stakeholders of the event. Therefore, along with changes in world standards, the management processes of the Four Hills Tournament were also transformed. In recent years, the focus has been on using modern technologies to contact fans, sports associations and the media. A dedicated website, profiles on social networks, as well as an application supporting marketing activities in other channels have been created. The application also allows supporters gathered under the jumps to participate in the event at different levels. Solutions that meet current standards are also created special packages and promotions for participants at selected tournament partners in individual host cities. To facilitate the sale of tickets for the main qualifiers and competitions, a website has been created that allows fans from all over the world to buy tickets starting September each year. 
Figure 5. Model of a network sporting event

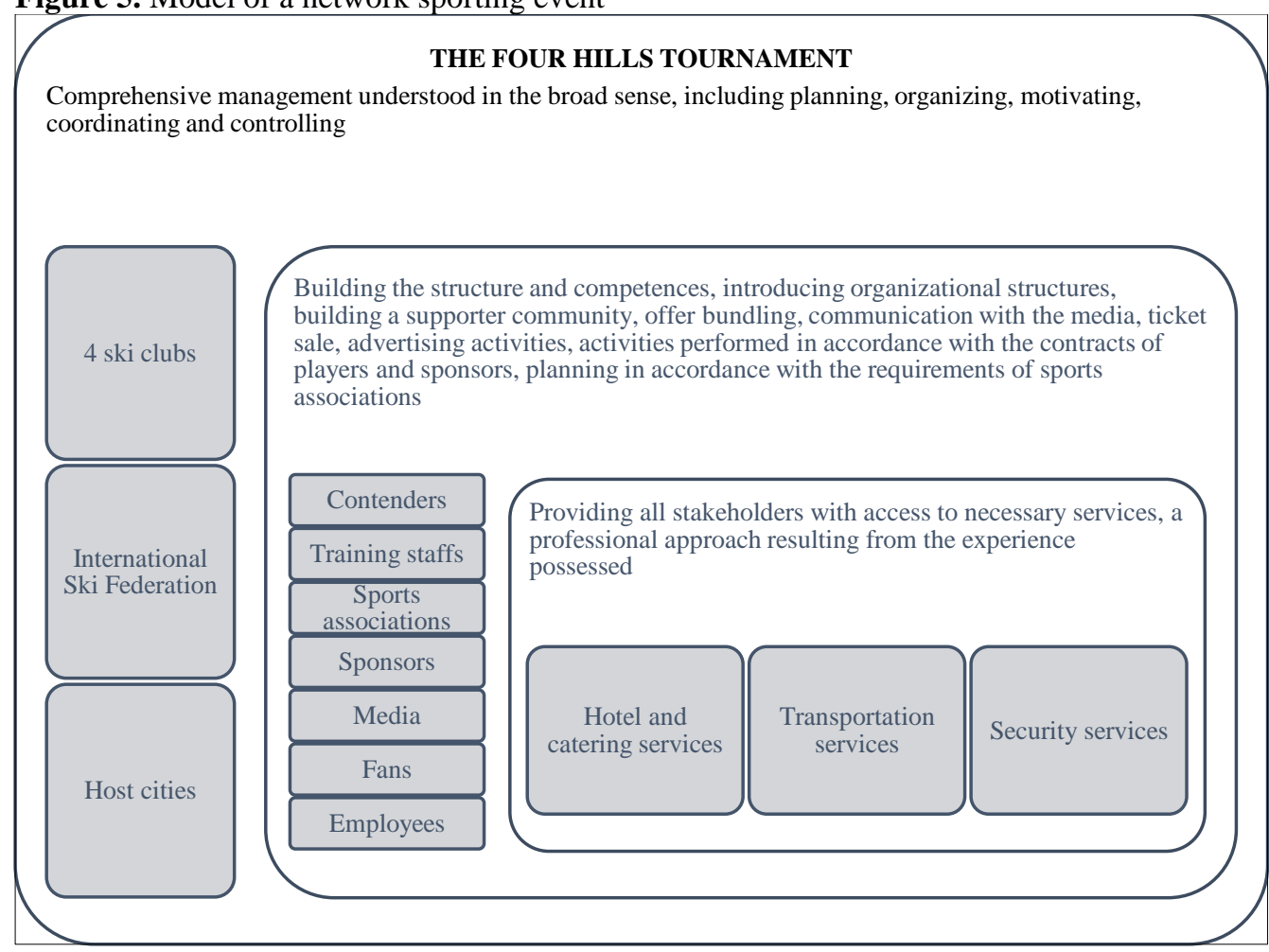

Source: Own study.

The proposed model of a network sports event refers to the Four Hills Tournament as an international event. The main organizers, i.e., the previously mentioned four ski clubs -Skiclub 1906 Oberstdorf, Skiclub Partenkirchen (SCP), Sport Club Bergisel (SC Bergisel), and Skiclub Bischofshofen, as well as the International Ski Federation and host cities, must ensure comprehensive management activities and distribute them among themselves while working closely together. The next level concerns the key stakeholders of the event, without which the tournament could not take place, i.e., players and associated training staffs or sports associations, sponsors, fans and the media.

All activities carried out must comply with the guidelines provided by the main organizers, taking into account the relationship between stakeholders. Substitution and complementary services are also of considerable importance. For all participants of the tournament, there is a professionally prepared hotel and catering base, security for all participants, or transport services extremely important in the context of cross-border and network events. All these elements form the whole of a comprehensive network of sports event connections, where each part is of great importance for the final result and building the image and efficiency of the 
tournament. Therefore, strong cooperation based on trust and experience become the essence of network connections during the organization of sporting events.

\section{Summary}

The literature on the subject lacks references to the organization of network sporting events. However, it can be assumed that this is a new approach on a global scale, resulting from changing socio-economic conditions. It is becoming increasingly difficult for one enterprise, city or state to organize an event without the help of other entities. These events ceased to be profitable for them, thus depriving fans of the chances of an extraordinary sports experience. Therefore, some evolution in this aspect is visible internationally. Putting the importance of relationships and cooperation in the minds of our stakeholders brings positive changes.

Indicating strong and stable relations between stakeholders of sporting events translates into desirable market behaviour of all entities. This leads to an improvement in the international position of the event, emphasizing its significance for fans and athletes. The possibilities of establishing such relationships depend on the organization's ability to build trust, mutual understanding of the parties to the relationship, a long-term perspective of cooperation, communication and mutual involvement in the continuous development of relationships.

\section{References}

Budner W. (2012), Organizacja wielkich imprez sportowych jako wyraz wzrostu konkurencyjności miasta, w: Gulczyński W. (ed.) Lokalne i regionalne problemy gospodarki przestrzennej, Wydawnictwo Wyższej Szkoły Biznesu w Gorzowie Wielkopolskim, Gorzów Wielkopolski, pp. 35-46.

Czakon W. (2005), Istota relacji sieciowych przedsiębiorstwa, „Przegląd Organizacji”, No. 9, pp. 10-13.

Grix J., Lee D. (2013), Soft Power, Sports Mega-Events and Emerging States: The Lure of the Politics of Attraction, Global Society, 27:4, 521-536, DOI:10.1080/13600826.2013.827632.

Herstein R., Berger R. (2013), Much more than sports: sports events as stimuli for city re-branding, "Journal of Business Strategy", Vol. 34, No. 2, pp. 38-44.

Iwan B. (2010), Nowe trendy w marketingu sportowym, „Zeszyty Naukowe Polityki Europejskie, Finanse i Marketing”, No. 3(52), pp. 353-367.

Kim J.W. (2010), The worth of sport event sponsorship: an event study, "Journal of Management and Marketing Research", Vol. 5, pp. 1-14.

Krzyżanowski L. (1999), O podstawach kierowania organizacjami inaczej, PWN, Warszawa.

Nufer G., Bühler A. (2010), Establishing and Maintaining Win-Win Relationships in the Sports Sponsorship Business, „Journal of Sponsorship”, Vol. 3, No. 2. 
Rudawska E. (2011), Interesariusze w marketing relacji na rynku usług sportowych, „Zeszyty Naukowe Uniwersytetu Szczecińskiego. Ekonomiczne problemy usług", No. 690, pp. 153-165.

Shipway R., Fyall A. (2012), International Sports Events. Impacts, experiences and identities, Routledge, New York.

\section{Internet source}

https://www.vierschanzentournee.com/en. 